\title{
The Perspectives of Human Freedom in a Post-Pandemic Social Reality
}

\author{
Wiktor Możgin \\ Ph.D. Student, Jagiellonian University in Kraków (Kraków, Poland) \\ E-mail: wiktor.mozgin@doctoral.uj.edu.pl \\ https://orcid.org/0000-0001-5744-8103
}

Możgin, Wiktor (2020) The Perspectives of Human Freedom In a Post-pandemic Social Reality. Ukrainian Policymaker, Volume 6, 63-73. https://doi.org/10.29202/up/6/7

\begin{abstract}
What will the post-pandemic world be alike? This is undoubtedly an issue that interests many people around the world. One thing is certain - the world after the pandemic caused by the SARS-CoV-2 virus will be different. This is primarily due to the noticeable processes of redefining the fundamental spheres of human functioning. This article presents a different perspective on the fight against a deadly virus because the essential aspect that is taken into account is the concept of social freedom. The different view of the coronavirus narrative lies in the pragmatic approach that allows indicating the processes and mechanisms of limiting social freedom under the pretext of fighting the SARS-CoV-2 virus. The research methods used for this purpose, characteristic of social sciences and humanities, make it possible to determine the discourse according to which the authorities of individual countries operate. Interesting in this context is also the process of imposing prohibitions and orders from society, which, through social apathy and fear of responsibility, will, in the future, become a social norm, thereby legitimizing the nonhumanistic state control over society.
\end{abstract}

Keywords: global pandemic, SARS-CoV-2 virus, human freedom, responsibility, social determinism, biopower, social annihilation

Received: May 10, 2020; accepted: May 29, 2020

\section{Introduction}

A pandemic caused by the SARS-CoV-2 virus has today mastered virtually every sphere of human functioning. It is difficult to find an area of life that would not be directly or indirectly affected by the effects of a global pandemic. Today, the international community is facing the challenge of defeating this virus, but despite the passage of several months, we still do not know what each of us is dealing with. In mid-May, some media published a list of 11 pandemic questions that the global community is still unable to provide an exhaustive answer (Lopez et al., 2020). These questions rely on the number of people who will be infected and deaths

(C) Możgin, Wiktor, 2020 
caused by infection or about the invention of the SARS-CoV-2 vaccine. However, the list of these questions is not exhaustive, as it is also essential to know the effects of a pandemic. Today, in China, the United States, Russia, Germany, Italy, Spain, Great Britain, Ukraine, but also in other countries, there is a discussion on finding the right way out of the crisis. The first step is undoubtedly to invent a measure that would stop the spread of the virus. The global community should speak with one voice because only through social solidarity, not egoism, will it be possible to stop the deadly virus. But the current situation is slightly different from the assumed, because Donald Trump after he stopped funding the World Health Organization (WHO), postulates the legitimacy of using the hydroxychloroquine agent in the process of preventing the virus (Karni, et al., 2020). In turn, the American scientific community and the governments of some countries, including Poland, see hope in the fight against the SARSCoV-2 virus through the use of Remdesivir (Kolata et al., 2020). In this context, the question also arises, which measure will be the most effective? Is it necessarily a vaccine or maybe the invention of an effective drug?

It is worth remembering what effects the hasty use of the swine flu vaccine in the United States in 1976 led to. At that time, a poorly tested vaccine led to a rare neurological disorder, Guillain-Barré Syndrome, in up to 450 people, which in turn had more negative effects than the symptoms caused itself by the flu (Lopez, et al., 2020). The second step will certainly be to overcome the effects of the crisis that resulted in the halting of global processes caused by the spreading pandemic. That is why it is reasonable to think about what will be the post-pandemic world today.

However, it is worth starting these divagations with the most existential and fundamental thing, namely, to consider the nature of post-pandemic man, taking into account, in particular, the issue of freedom, which has been so widely promoted and cherished by the global community over the last few centuries. Therefore, the purpose of this article is to analyze the effects of a pandemic caused by the SARS-CoV-2 virus on ethics, morality, but above all freedom of postmodern man. A multifaceted statement of contemporary events will be presented concerning philosophical, anthropological, sociological, and cultural studies perspectives. This will allow us to indicate processes that prove the redefinition of human nature while being strictly inclusive. In this context, it is worth assuming that humanity is a social organism that has its forms of evolution. Referring to the humanities and social sciences, it will be reasonable to state that human civilization has gone through certain stages of development that have been conceptually explained by the theories of pre-modern, contemporary and post-modern societies. These concepts, tradition, and methodology of the humanities and social sciences use aspects of ethicality, morality, and freedom in the human anthropological project, pointing to some variables testifying to the evolutionary process of man and the redefinition of his constitutive features.

\section{Freedom in a Post-modern Society}

These considerations require an explanation of the conceptual matter in which we will be moving. This is primarily because each of us can understand and feel the concept of freedom differently. If everyone were to answer the question: "What is freedom?" most certainly, the answers would be different. Nevertheless, they would all relate to a simple universal scheme of claiming that there is "freedom from" and "freedom to". But, given the broad scope of the concept of freedom, we can talk about physical freedom, psychological freedom, legal 
freedom, and moral freedom. It is also worth remembering that when discussing the concept of freedom, one should often take into account its comprehensive, inclusive nature. Thus, the narrative vector of this article will not be directed towards the formulation of the concept of freedom, but about the processes associated with this term, implemented in today's world situation, which is the result of a pandemic caused by the SARS-CoV-2 virus.

Freedom is closely correlated with the concept of responsibility. Today, the belief that we associate freedom primarily with the democratic system has become established. But is it really so? Can a democratic system, or otherwise, representative democracy really be related to the notion of freedom? Is freedom, in this socio-political context, not limited essentially to the act of choosing the authority that decides for us in which political, legal, economic, social, cultural reality we will live for the next few years? Each of us gets rid of our freedom in fear of the proverbial Hobbesian Leviathan. This is because freedom means responsibility, which is why most people, fearing responsibility, agree to get rid of some of their freedom (Shaw, 1903: 228-230). Therefore, responsibility has become an unpopular concept, which is often avoided in the political and scientific community, because it is primarily reluctantly accepted by a generation that does not approve of any moralizing and compliance with ethical norms of conduct. It often causes open social hostility, because the immanent implication of human behavior is the belief that his actions and life position are determined only by circumstances over which he has no control. It is primarily a narrative direction of nineteenth-century philosophers. However, this rejection of responsibility is caused by fear, which also translates into the concept of freedom. So, this perspective refers to the claim that many people are afraid of freedom because the possibility of building their own lives is at the same time a permanent challenge, or in other words a task that requires a proper discipline that man must impose on himself to achieve his goals (Hayek, 1960: 124-126; 201-212).

The belief that all natural phenomena are determined only by previous events, or are subject to specific laws that can be determined and appropriately formulated, concludes that external circumstances determine human deeds and rational and irrational relationships occurring in his mind, given the postulate that man is part of the natural system of the world (Fromm, 2005: 7880). The concept of universal determinism in the context of these considerations means that the global pandemic caused by the SARS-CoV-2 virus is an implication of previous phenomena and processes that shaped reality at the time. Man, as an integral part of this system, was also the driving force that led to the pandemic. In this way, the already mentioned nineteenthcentury deterministic concept is expanded, allowing a man to influence his fate. Here again, the issue of freedom and the responsibility that comes with it must be returned. So if a man has the driving force, and thus the freedom to make specific decisions, then he should also be assigned due responsibility for these acts, which is, after all, such an inconvenient concept for every man. So how does this responsibility translate into decisions taken by contemporary, or otherwise, post-modern society? What is post-modernity in the context of these considerations?

The second half of the twentieth century and the beginning of the twenty-first century is a transition period between the modern world, in which the idea of the imperfection of material existence and the possibility of improving this state prevailed by subjecting all processes to reason. The post-modern world, which in the understanding of Zygmunt Bauman, deprives itself of the need for any moral theories - ethics, philosophy, religion, beliefs — and society can independently define moral principles, without resorting to assumptions and processes based on the Cartesian idea of the rationality of truth. The Bauman's characteristic of postmodernity boils down to the processes of desacralization and secularization of the contemporary 
culture of Western societies. Postmodernity forces people to have moral independence and autonomy, religion, and other ethical regulators are no longer needed. Social affirmation of the post-modern world boils down primarily to the concept of guaranteeing universal freedom on a worldwide and moral level (Bauman, 2000: 36-41; 181-183). However, this does not mean that we are dealing with an uncontrolled state today because, in certain crisis moments, we agree that our freedom, not only moral and ideological, should be limited in the name of the principle of security for us all. This is a picture of the state of reality with which we are dealing in a world engulfed in a pandemic.

The contact of post-modern man with the danger of threatening his existence exposes the weakness of human nature. It is visible above all in the moments when specific actions should be taken to fight the SARS-CoV-2 virus, and with that to be responsible for their actions. The main question that today interests many people around the world is whether the global lockdown was too radical? What way of fighting was more effective? Looking at a country like Sweden, which has not imposed glaring restrictions and bans on its citizens due to the spreading virus, today it is fighting the problem of the growing number of cases, which is drastically manifested especially in social care homes, where people staying there are served morphine, thus applying active euthanasia to them (Savage, et al., 2020). In turn, in neighboring Denmark, you can hear words of criticism about the complete suspension of the functioning of the state. Jens Otto Lunde Jørgensen, a professor at Aarhus University Hospital, says that the Danish healthcare system controlled the situation, and pressing the "STOP" button for Denmark was completely ill-considered move (Jørgensen, et al., 2020).

Nevertheless, the concept of freedom in its inclusive nature also refers to human behavior and deeds, which are limited in crisis moments. Denmark and many other countries where prohibitions and orders for appropriate conduct have been introduced are an excellent example of a vector for further consideration. Today, we are witnessing a restriction on the freedom of post-modern man, whose goal is to overcome the deadly virus. It would seem that it is necessary because post-modern man, according to Bauman's characteristics, got rid of these necessary qualities allowing him to impose appropriate discipline, taking into account the aspect of morality and ethics. The restrictions imposed from above would serve as an effective tool to stop social annihilation, which is the result of SARS-CoV-2 virus interaction. What remains to be resolved, however, is to what extent can these human freedoms be restricted? And no less important, what shape will socio-political-economic relations take as a result of the imposition of such necessary restrictions?

\section{Human Freedom in a Post-pandemic World}

Today, during a pandemic caused by the SARS-CoV-2 virus, the Bauman paradigm of the post-modern world is collapsing. This is primarily due to the responsibility that should be borne for decisions taken both during and after the pandemic has ended. Responsibility in post-modern times, as has already been mentioned, has become an unpopular concept, a word that pragmatic thinkers, researchers avoid, because it is taken with reluctance and boredom by an individualized generation that was able to create the specific morality and with it an approach to particular problems. Postmodernity also frees people from the past and the need to remember. Therefore, the past does not create a typical continuous structure of events with the present. There is a hermeneutic approach to experiencing everyday life as something completely new. This does not change the conviction about universal determinism, where 
man has causative potential. Therefore, post-modernity does not break with determinism but indicates a redefinition of existing values and attitudes.

Milan Kundera, in his work The Unbearable Lightness of Being, emphasized that existence without deeper emotions is meaningless, everyday life, everyday matters are light, yet they do not bring satisfaction (Kundera, 1984: 47-48). Contemporary society, by falling into the trap of permanent consumerism and a nomadic way of life in a globalized world, has broken with a sense of responsibility for its future. With this, the paradigm of freedom has been violated. Today, the principle of social solidarity has been reversed, because solidarity is being isolated from others today. However, it is worth explaining this situation in a certain way, because isolation should only apply at the social level to prevent social annihilation. In turn, the principle of solidarity should undoubtedly be present in the rhetoric of contemporary international relations in the field of scientific and research cooperation. The invention of a measure to stop the spread of a virus in one country must result in its immediate distribution to other countries.

The issue of human freedom in the era of today's pandemic prompts reflection, which can be metaphorically reduced to the work Nineteen Eighty-Four by George Orwell. In particular, it is a fragment when the main character of the novel, looking out the window, sees his workplace - whose famous Ministry of Truth, and on it, and this is the most important in the context of these considerations, the inscription: "War is peace, Freedom is slavery, Ignorance is strength" (Orwell, 2018: 34-38). Nowadays, this inscription can be used to describe phenomena and processes occurring in the modern world. The symbolic character of Orwellian Nineteen Eighty-Four presents a complicated and still unexplained situation that was determined by human behavior during the pandemic. Therefore, it will be used as a background for reflection, providing a direction for further narration.

\section{"War is Peace" Metaphore}

What does war mean peace? First of all, the world has waged war on a virus that has slowed down all world processes. Today, war is not understood in the traditional Clausewitz sense, but it is a new type of war. This biological war undoubtedly plays its role for various entities, also greatly influencing the issue of freedom. There is no doubt that this war is fought by a man who expects concrete results from it. The purposefulness of man's actions is assumed in his nature, because in Homo sacer by Giorgio Agamben it is noted that one of the constitutive elements of the category of life next to the concept of $d z o \bar{e}$ is the concept of bios, which refers to the sphere of action - praxis - aiming at a goal, as in the case of man meant happiness - eudaimonia (Agamben, 2008: 17-21). Well, if the pursuit of a goal is assumed in the nature of every human being, then each obstacle will constitute a restriction of freedom, which is an existential part of this process. Today, such a goal is to overcome the spread of SARS-CoV-2 virus. So this is a war that, after Carl Schmidt, can be blamed in a way on the political buckle.

Actually, politics accompanied the pandemic events from the very beginning. After all, through the decisions of state authorities, further restrictions were consistently introduced. The concept of freedom in this situation was constantly subject to redefinition because what could be done yesterday was becoming forbidden today. There is no doubt that all actions affecting the issue of human freedom were aimed at stopping a pandemic. Often, the basis for political decisions were model simulations of the spread of the SARS-CoV-2 virus both in individual countries and around the world (Rhodes et al., 2020: 253-254). However, the question arises 
to what extent are these simulations, for example, proposed by British Imperial College, effective and reliable? Most countries base their political decisions regarding the introduction of quarantine restrictions, and thus restrictions on freedom, based on this type of simulation. Today, from the perspective of several months — this article is written in mid-May 2020 — it can be concluded that these simulations and models were often overestimated. This had, of course, political consequences, but above all, economic ones. Due to restrictions imposed on entrepreneurs, which in most cases resulted in the suspension of production or change of production profiles, the economies of many countries will fall into a post-pandemic recession.

Thus, by waging war against the deadly virus, the state, by introducing many restrictions on the functioning of economies, tries to respond appropriately to pandemic circumstances. By using the Orwellian metaphor cited, governments are adapting to biological and pandemic war, changing the narrative of their policies. From the perspective of the Polish state, this is manifested, for example, by the adoption of a special law regulating the sale of strategic items in the fight against the virus (masks, respirators, etc.). Of course, for the sake of the state, the goal is to ensure the safety of citizens, while for companies that produce the items as mentioned above, the goal is to sell them at the best price and in the most considerable possible quantity, i.e., following the principles of economics, it is in the interest of companies to make a profit. Of course, state-owned enterprises are required to comply with appropriate operating criteria, but this should not apply to private enterprises.

Striving for peace through war also means having effective combat tools. During the reign of SARS-CoV-2 in the United States, representatives of the Democratic Party drew up a bill H. R. 6666, which refers to the so-called coronawhistleblowing, in other words informing the relevant authorities about cases of violation of quarantine, or violation of restrictions imposed on citizens in connection with the SARS-CoV-2 pandemic. The case is interesting because this information will be heavily paid by the government, as the bill for its implementation assumed an amount of 100 billion dollars (Authenticated U.S. Government Information, 2020). Yes, it is the responsibility of every citizen to inform the authorities about violations of applicable rules. However, the question arises whether it will be an effective tool in the fight against a deadly virus, or a means to enrich a specific group of people? In this way, the authorities indirectly interfere with the private sphere and the freedom of their citizens. In turn, the Israeli special services Shin Bet by eavesdropping on phone calls and special applications tracked suspects as carriers of the SARS-CoV-2 virus, or people in quarantine (Scheer, et al. 2020). And in Germany, for example, tests for the presence of SARS-CoV-2 virus in the body were introduced in the Carolinum Junior High School in the Neustrelitz city. If they undergo such tests, which indicate a negative result, people will have more rights than people who did not undergo the tests, because it is a matter of voluntariness. These rights are manifested in access to more rooms, fewer restrictions on moving around the school. In Carolinum Junior High School, even separate entries were created for those who underwent tests and obtained a negative result, and those who refused such tests (Das Elternportal von Focus et al. 2020).

Analyzing the above examples, one may risk the thesis that they constitute an exemplification of state interference in the sphere of the personal freedoms of citizens. Fighting a war with a deadly virus should not mean extensive increasing control over society. In a specially prepared open letter, over 300 scientists from 26 countries warn of unprecedented surveillance of society through coronavirus applications that affect human freedom (Greis et al., 2020). The post-pandemic world is a world of control over everything that man does (O'Neill et al. 2020). The question then arises, is it compatible with democratic principles that are so loud 
in Western countries? Perhaps the pandemic has influenced the redefinition of the concepts of democracy, freedom, and civil rights. And today a new order is being shaped, where permanent surveillance will become the norm and a person fearing any liability will agree to further restrictions on his freedom? War is peace, but what concessions should man agree to achieve that peace? Where is the harmony between the pre-modern values of surveillance and postmodern ones?

\section{Freedom vs. Slavery in Post-pandemic Society}

In the age of pandemic caused by the SARS-CoV-2 virus, social isolation was the method that was used to overcome the threat. From every side, a person heard the postulate "Stay at home". Jonathan Hellewell, along with other researchers, claimed that the so-called "population blockade" will have negative effects (Hellewell, 2020: 253). In the previous part of the article, the impact on the economy was mentioned, because everyday governments of countries count financial losses caused by social isolation. There is no doubt that the result of this state of affairs will be the global economic crisis. In the United States, the biggest recession since the crisis of the early 1930s has been rumored for some time. Today, the American people are plunged not only in the fight against the deadly virus but also in the fight for their own rights to a normal existence. This is done through mass protests against the restriction of the freedom of Americans who, as a result of a pandemic, had to stay in their homes. People in more than 20 states came out on the streets with banners “Open America now!". In the face of the threat of virus infection, will the state authorities take steps to weaken the restrictions? It can be presumed that rather "not" because, in the United States, there is the highest number of people infected and the highest mortality caused by SARS-CoV-2 virus. So, what social consequences will it have?

So if slavery, metaphorically identified with isolation, should contribute to the increase of people's freedom, then the situation looks quite the opposite. In this context, it is worth looking at ideas from some countries regarding the introduction of "immunity passports" issued to people who have overcome infection with coronavirus (Coleman, et al. 2020). The consequence of such actions will certainly be social division, on those who are allowed to lead a normal life and those who will be forced to remain in isolation for an indefinite period of time, because such an indicator will be either to cope with the disease or to take appropriate medicines whose invention is burdened with a longer time perspective. Therefore, biological and social inequality will be normalized, which will lead to economic and social stratification. Similarly to the situation mentioned above in the Carolinum Junior High School, where students are also separated due to surrendering or failing to be tested for the presence of SARSCoV-2 virus in the body.

Going in this direction can be reduced to the claim that the so-called world panopticon. To refer to this context belongs to the project of the perfect prison of Jeremy Bentham, where there is one supervisor who is invisible to the rest of the prisoners. Still, in fear of the consequences of control, each of them follows the rules. Today's pandemic situation allows us to state that we live in an identical panopticon. It is undoubtedly the internet world, or the so-called world 2.0. All of our activities have been moved to the Network, and therefore the chance to exercise control over us has undoubtedly increased. Each click on the keyboard button can be monitored by the relevant state services. That is why every man, like in panopticon, rather tries to follow the rules, because it is unknown at what moment our actions will be controlled. No 
one wants to be responsible for acts on which the state imposes certain restrictions. From this comes the straightforward conclusion that the pandemic was and, in this case, effectively used to limit social freedom. Man nowadays expresses his approval for self-isolation and with it the restriction of his own freedom not only for fear of virus, but above all for fear of responsibility. A pandemic in this context is merely a mechanism that drives social hysteria. So, to achieve freedom, i.e., to overcome the fight against SARS-CoV-2 virus, and to return to normalcy, society is in captivity, or in other words, social isolation. So again, the Orwellian metaphor finds application in today's reality.

\section{Ignorance is Strength: From Orwellian Senses to Current Pandemic Ones}

What could the Orwellian metaphorical phrase "ignorance is strength" mean during a pandemic? However, before this question is answered, it is worth recalling the inclusive nature of the concept of freedom. It includes, among others, aspects of morality and ethics of decision making. Being free does not mean acting with free will, because this definition is redefined today. Free will today is limited by the scope of the rights and obligations that society imposes on society.

Nevertheless, society should be able to influence this scope of freedom, and there should be so-called social approval. Traditionally, people get rid of the ability to make decisions for the representatives of their choice, thus allowing a small group of people to decide on living conditions for several years to come (Svyrydenko \& Możgin, 2019: 91-92). It is a mechanism that most people around the world have got used to today. However, in crisis moments, restriction of freedom by introducing special regulations takes on a new meaning. In this context, axiological issues undoubtedly play an essential role, because the basic problem is the level to which one can interfere in the sphere of social freedoms. So, returning to the question, which means the statement that ignorance is a force, it is worth implementing in its semantic sphere also those mentioned above ethical and moral aspects.

Ignorance is also deciding what is better and what to give up. The problem related to this was particularly noticeable in Italy when in the absence of adequate material security, tough decisions were made, which in the context of our considerations, we can refer to the issue of moral freedom. What to do? Who to save first? For anyone in such a situation, it would be a huge problem. They are resulting not only from purely pragmatic reasons but above all moral and ethical.

Generally speaking, the sphere of medicine has been thoroughly redefined today. Nowadays, individual states, interfering in the private sphere of their citizens, strive to ensure their security. Nevertheless, under cover of this concern lies an unlimited range of control. Michel Foucault described this type of action on the part of the state as biopower (biopouvoir). The goal of biopower is to control people's lives (Foucault, 2014: 23-25). It is interesting, however, that in times of crisis, this control goes to a different level and concerns not individuals, but the collective body, which is the global community. This is the way of thinking that we are dealing with today because man becomes the object of a potential threat. Today, following this logic, we go beyond the dimension of ethics and morality, pursuing the goal of overcoming the SARS-CoV-2 virus.

In his works, Michel Foucault clearly shows how the health care system has been redefined and a today is an effective tool for controlling and monitoring the public worldwide (all the countries do it today staying on the humanistic positions, but these practices create the 
challenges of redefining the social architecture worldwide). The French philosopher believes that the sphere of medicine has evolved into social medicine, at the core of which is the technology of the social body. In a capitalist society, the human body is only a biopolitical reality, and medicine is only a biopolitical strategy. It follows that the medical sphere is nothing more than a mechanism by which power exercises control over man (Foucault \& Deleuze, 1977: 207-211). In this context, one fundamental question arises, whether will ever ordinary man have a chance to free himself from this permanent control? Observing the modern world in which the nomadic and consumerist way of life overwhelmed the majority of society, one can certainly answer in the negative. This is primarily due to the belief that the human body, which is the material sphere of man, is more important today than the axiological sphere, i.e., the one based on values, morality, and ethics.

Thus, to say that ignorance is a force that reduces this narrative into two related aspects. The first is that society, fearing the deadly virus, is becoming more selfish, often caring for its particular interests. It can be presumed that this is a consequence of a specific strategy based on materialistic assumptions, devoid of ethics, and morality. In turn, the second aspect concerns the mechanisms used in some developed countries, that instrumentalize the pandemic situation and, by implementing the biopolitics assumptions, strive to control society.

\section{Conclusions}

The post-pandemic world, referring in this context to the post-modern world, will undoubtedly be different. First of all, due to the issue of freedom so widely discussed in this article, each of us will voluntarily be able to renounce to ensure our national security. It follows from this that over time, those restrictions that are supposed to provide us with protection and which limit our freedom will become the norm and will enter the ordinary life, such as restrictions related to passing control at airports after September 11, 2001. Today, none of us are thinking about protesting against airport restrictions associated with giving control procedures. It will be the same in the post coronavirus world when the relevant services measure our body temperature before entering the airport terminal or onboard an aircraft.

However, when talking about body temperature or pressure, one can go a step further and say that in a post-pandemic world not only these physiological features of our body will be controlled, but it can be extended to our emotions, which are also a biological phenomenon of our body. The SARS-CoV-2 pandemic nowadays is an excuse to increase this control. It is no longer a difficult task to imagine a situation when human political views will be judged by the click of a button on the TV remote control. Nevertheless, this control over human emotions will be a much more effective mechanism in this context. All this boils down again to Michel Foucault's rhetoric regarding biopolitics.

From the considerations presented in this article, there is also a conclusion that in the post-pandemic world, there is unlikely to be a redefinition of media discourse. This is due to the fact that in $21^{\text {st }}$ century, man is overwhelmed by media terror because virtually every news channel presents materials on the SARS-CoV-2 virus (Aven et al. 2020). However, it is worth noting that this narrative is often devoid of practical comments based on scientific conclusions. Today, it is still unknown what virus pathogen attacks the human body, and the more it is unknown how to fight it. It is a paradox that, despite a large amount of information about coronavirus, a person does not receive the necessary tool in the form of an answer to a seemingly simple question, what should I do next? How should I proceed? 
The final conclusion of this article is the fact that we will certainly be imposed and then legalized new standards and obligations, which will initially constitute a restriction on our freedom. It then will become so common that no one will pay attention to their application. Thus, another crisis and subsequent regulations imposed on people will become the norm in everyday life. For those in power in some countries, it will be another chance to increase their control over society. Therefore, it is worth analyzing a pandemic not only from the perspective of statistics of the number of cases but above all, considering it in terms of rational effects regarding the sphere of ethics, morality, and freedom. However, in this matter, the basic question is whether a post-modern man is ready to take up this challenge? At the current stage of reflection on the effects of a pandemic, this question is rather rhetorical. Nevertheless, the situation referred to in this article arises, referring to the words of Alain Finkielkraut, from the weakness of man and his fear of being responsible for his actions (Bielecki, et al., 2020). Therefore, at this stage, one thing remains certain because the paradigm of the post-modern world will certainly change radically due to the impact of the pandemic caused by the SARSCoV-2 virus.

\section{References}

Agamben, Giorgio (2008) Homo sacer; suwerenna władza i nagie życie, Warszawa.

Authenticated U.S. Government Information. H. R. 6666 (2020) https://www.govinfo.gov/ content/pkg/BILLS-116hr6666ih/pdf/BILLS-116hr6666ih.pdf

Aven, Terje, and Frederic Bouder (2020) The COVID-19 pandemic: how can risk science help? Journal of Risk Research, https://www.tandfonline.com/doi/full/10.1080/13669877.20 20.1756383

Bauman, Zygmunt (2000) Liquid Modernity, Cambridge.

Bielecki, Jędrzej (2020) Alain Finkielkraut. Wirus zatrzymat chocholi taniec konsumpcjonizmu, https://www.rp.pl/Plus-Minus/304109996-Alain-Finkielkraut-Wirus-zatrzymalchocholi-taniec-konsumpcjonizmu.html

Coleman, Justine (2020) Chile to issue world's first 'immunity passports' to people who have recovered from coronavirus, https://thehill.com/policy/international/americas/493805chile-to-issue-worlds-first-immunity-passports-to-people-who

Das Elternportal von Focus (2020) Schule kennzeichnet Nicht-Infizierte mit grünem Punkt Psychologe schlägt Alarm, https://www.focus.de/familie/eltern/familie-heute/schulekennzeichnet-nicht-infizierte-mit-gruenem-punkt-psychologe-schlaegt-alarm_id

Greis, Friedhelm (2020) 300 Wissenschaftler warnen vor zentraler Datenspeicherung, https://www.golem.de/news/corona-app-300-wissenschaftler-warnen-vor-zentralerdatenspeicherung

Fromm, Erich (2005) Ucieczka od wolności, Warszawa.

Foucault, Michel (2014) Rzadzenie żywymi, Warszawa.

Foucault, Michel, and Gilles Deleuze (1977) Intellectuals and power, [in:] Language, CounterMemory, Practice: Selected Essays and Interviews, ed. by D. Bouchard, New York: 205-217.

Hayek, von Friedrich (1960) Constitution of Liberty, London.

Jørgensen, Jens (2020) Vi skulle aldrig have trykket på stopknappen, https://jyllands-posten. $\mathrm{dk} /$ debat/breve/ECE12074246/vi-skulle-aldrig-have-trykket-paa-stopknappen/ 
Karni, Annie, and Katie Thomas (2020) Trump Says He's Taking Hydroxychloroquine, Prompting Warning From Health Experts, https://www.nytimes.com/2020/05/18/us/ politics/trump-hydroxychloroquine-covid-coronavirus.html

Kolata, Gina (2020) How Remdesivir, New Hope for Covid-19 Patients, Was Resurrected, https:/www.nytimes.com/2020/05/01/health/coronavirus-remdesivir.html

Kundera, Milan (1984) The Unbearable Lightness of Being, New Your.

Lopez, German (2020) 11 questions about the coronavirus we still can't answer, https:// www.vox.com/2020/5/12/21248395/coronavirus-pandemic-covid-symptoms-testingchildren-mysteries

O’Neill, Patrick, Tate Ryan-Mosley, and Bobbie Johnson (2020) A flood of coronavirus apps are tracking us. Now it's time to keep track of them, https://www.technologyreview. com/2020/05/07/1000961/launching-mittr-covid-tracing-tracker/

Orwell, George (2018) Nineteen Eighty-Four, London.

Rhodes, Tim, Kari Lancaster, and Marsha Rosengarten (2020) A model society: maths, models and expertise in viral outbreaks, Critical Public Health, Vol. 30: 253-256. https://doi.or $\mathrm{g} / 10.1080 / 09581596.2020 .1748310$

Savage, Maddy (2020) Coronavirus: What's going wrong in Sweden's care homes? https:// www.bbc.com/news/amp/world-europe

Scheer, Steven, and Tova Cohen (2020) Israel extends coronavirus cell phone surveillance by three weeks, https://www.reuters.com/article/us-health-coronavirus-israel-surveillanc/ israel-extends-coronavirus-cell-phone-surveillance-by-three-weeks

Shaw, G. Bernard (1903) Man and Superman: Maxims for Revolutionaries, London.

Svyrydenko, Denys, and Wiktor Możgin (2019) The Soft Power of the State as a Dialectic of Contemporary Dependencies in the International Arena, Ukrainian Policymaker, Vol. 5, 2019: 89-98. https://doi.org/10.29202/up/5/10 